\title{
Feeding behavior of nauplii of the genus Eucalanus (Copepoda, Calanoida)
}

\author{
Gustav-Adolf Paffenhöfer, Kellie D. Lewis \\ Skidaway Institute of Oceanography, PO Box 13687, Savannah, Georgia 31416, USA
}

\begin{abstract}
The goals of this and following studies were to describe how nauplii of related calanoid copepods gather and ingest phytoplankton cells, and to compare their feeding behavior with that of copepodids and adult females of the same species. Nauplii of the calanoids Eucalanus pileatus and E. crassus draw particles towards themselves creating a feeding current. They actively capture diatoms $>10 \mu \mathrm{m}$ width with oriented movements of their second antennae and mandibles. The cells are displaced toward the median posterior of the mouth and then are moved anteriorly for ingestion. The nauplii gather, actively capture, and ingest particles using 2 pairs of appendages, whereas copepodids and females use at least 4 of their 5 pairs of appendages (second antennae, maxillipeds, first and second maxillae) to accomplish the same task. These nauplii are not able to passively capture small cells efficiently like copepodids and females because they lack a fixture similar to the second maxillae. Gathering and ingestion by late nauplii of E. crassus and E. pileatus require together an average of 183 $\mathrm{ms}$ for a cell of Thalassiosira weissflogii (12 $\mu \mathrm{m}$ width) and $1.17 \mathrm{~s}$ for Rhizosolenia alata (150 to $500 \mu \mathrm{m}$ length). Although nauplii of related species show little difference in appendage morphology, they differ markedly in feeding and swimming behavior. Their behavior is partly reflected in the behavior of copepodids and adult females.
\end{abstract}

\section{INTRODUCTION}

The significance of calanoid copepods in marine ecosystems has been addressed in numerous publications (e.g. Steele 1974, Frost 1987). Many of these publications focused on the quantification of rate processes in which calanoids play a major role, e.g. consumption of particulate matter, secondary production, and excretion of nitrogenous compounds. Contrarily, quantitative studies to determine how calanoids exist in the ocean, e.g. species-specific swimming, escape and feeding behavior, have been rare (see Gauld 1966, Strickler 1984 for comparative observations). Processes involving food gathering and ingestion of marine calanoid females have been described for less than 10 species (Alcaraz et al. 1980, Koehl \& Strickler 1981, Price et al. 1983, Price \& Paffenhöfer 1986a, b). Among the various stages of a calanoid copepod's life cycle nauplii appear to be the most sensitive, because their stage-specific mortality is higher than that of copepodids or adults (e.g. Paffenhöfer 1970). Several attempts have been made to describe the feeding processes of calanoid nauplii (Storch 1928, Gauld 1958, Marshall \& Orr 1956, Fernandez 1979). Their observa- tions, however, differed considerably. It appears that we do not yet fully understand how any calanoid nauplius gather and ingests food.

The immediate goals of our study were to demonstrate how nauplii of several related species gather and ingest phytoplankton cells, and compare these results with the feeding behavior of copepodids and adult females of the same species.

\section{MATERIAL AND METHODS}

Most of our investigations were conducted with late naupliar stages of Eucalanus pileatus, which is one of the characteristic calanoid species on the southeastern shelf of the USA (Bowman 1971). For comparison we investigated the oceanic Eucalanus hyalinus (Fleminger 1973) and E. crassus. Most of our observations were based on microcinematography of either tethered or free-swimming specimens. The nauplii were reared in the laboratory and usually preconditioned for 48 to $72 \mathrm{~h}$ to the food offered (diatom Thalassiosira weissflogii, $12 \mu \mathrm{m}$ cell width; Rhizosolenia alata, 25 to $40 \mu \mathrm{m}$ cell width, 150 to $500 \mu \mathrm{m}$ 
cell length) usually at concentrations near $1.0 \mathrm{~mm}^{3} \mathrm{l}^{-1}$ Algal concentrations were determined using an inverted microscope (Paffenhöfer 1984). Concentrations between 1.0 and $3.0 \mathrm{~mm}^{3} \mathrm{l}^{-1}$ of phytoplankton were chosen because these concentrations are close to those found in upwelled water masses in which nauplii of E. pileatus are abundant (Paffenhofer et al. 1980). E. hyalinus reproduces rapidly at similar food concentrations in the upper $100 \mathrm{~m}$ (Cowles et al. 1987). We assumed that nauplii would occur in the same stratum as adult females. Nauplii were tethered several hours prior to filming. All studies were con-

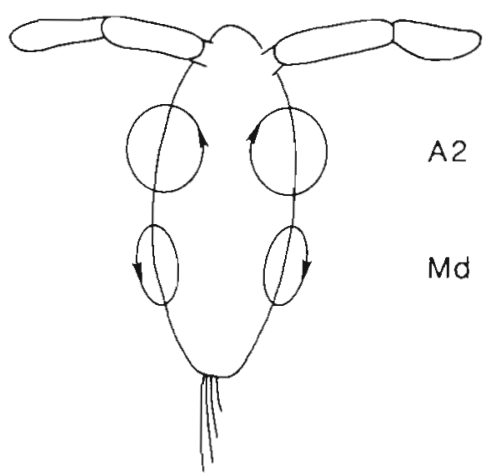

A 1

Fig. 1. Eucalanus pileatus. Ventral view of a nauplius stage 5 (N5). Schematic of the rotation of the second antennae (A2) and mandibles (Md). Arrows indicate direction of motion, and are here at a position when $\mathrm{A} 2$ pulls away from $\mathrm{Md}$

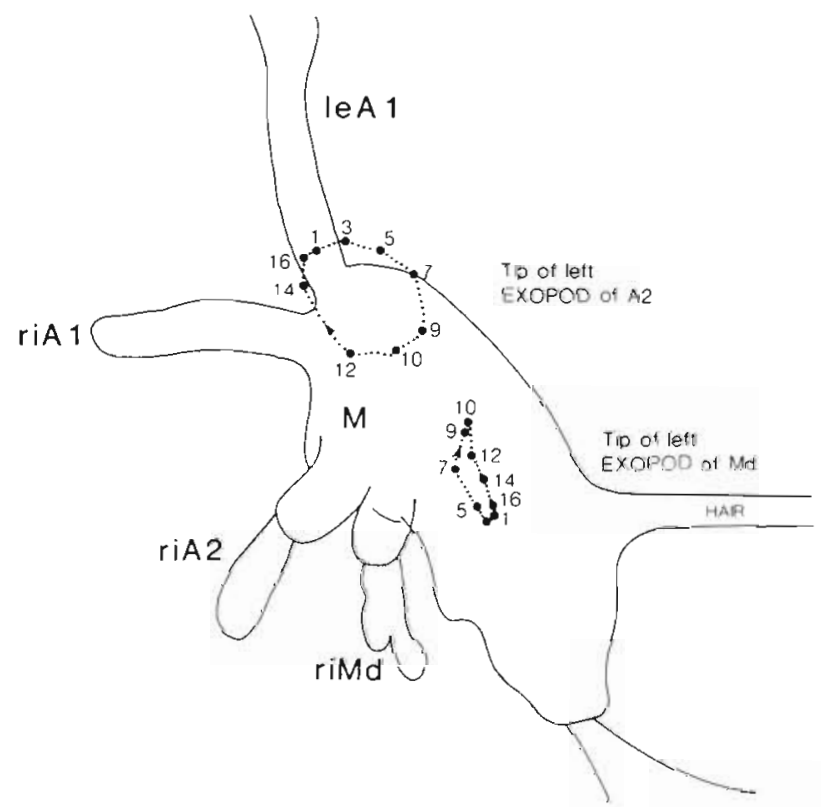

Fig. 2. Eucalanus pileatus. Ventro-lateral view of an N6. Timeseries of motion of the tip of the exopod of left $A 2$ and of left Md. Right first antenna (riA1), riA2 and riMd are out of focus. M: mouth; leA1. left first antennae. Numbers are frame numbers. Time between frames is $4 \mathrm{~ms}$ ducted at $20^{\circ} \mathrm{C}$. The filming equipment used has been described by Alcaraz et al. (1980). For comparative purposes we filmed early copepodid stages of $E$. pileatus and E. hyalinus. Films were made at 125 or 250 frames $\mathrm{s}^{-1}$ which resulted in 32 or $16 \mathrm{~s}_{\text {film }}{ }^{-1}$, respectively. All films were taken between midday and late afternoon. They were analyzed using a Vanguard Motion analyzer to determine the following variables: food gathering and ingestion behavior, routes and velocities of algal cells drawn towards the copepods, frequency of appendage motion, and lengths of active and passive (no appendage motion) periods.

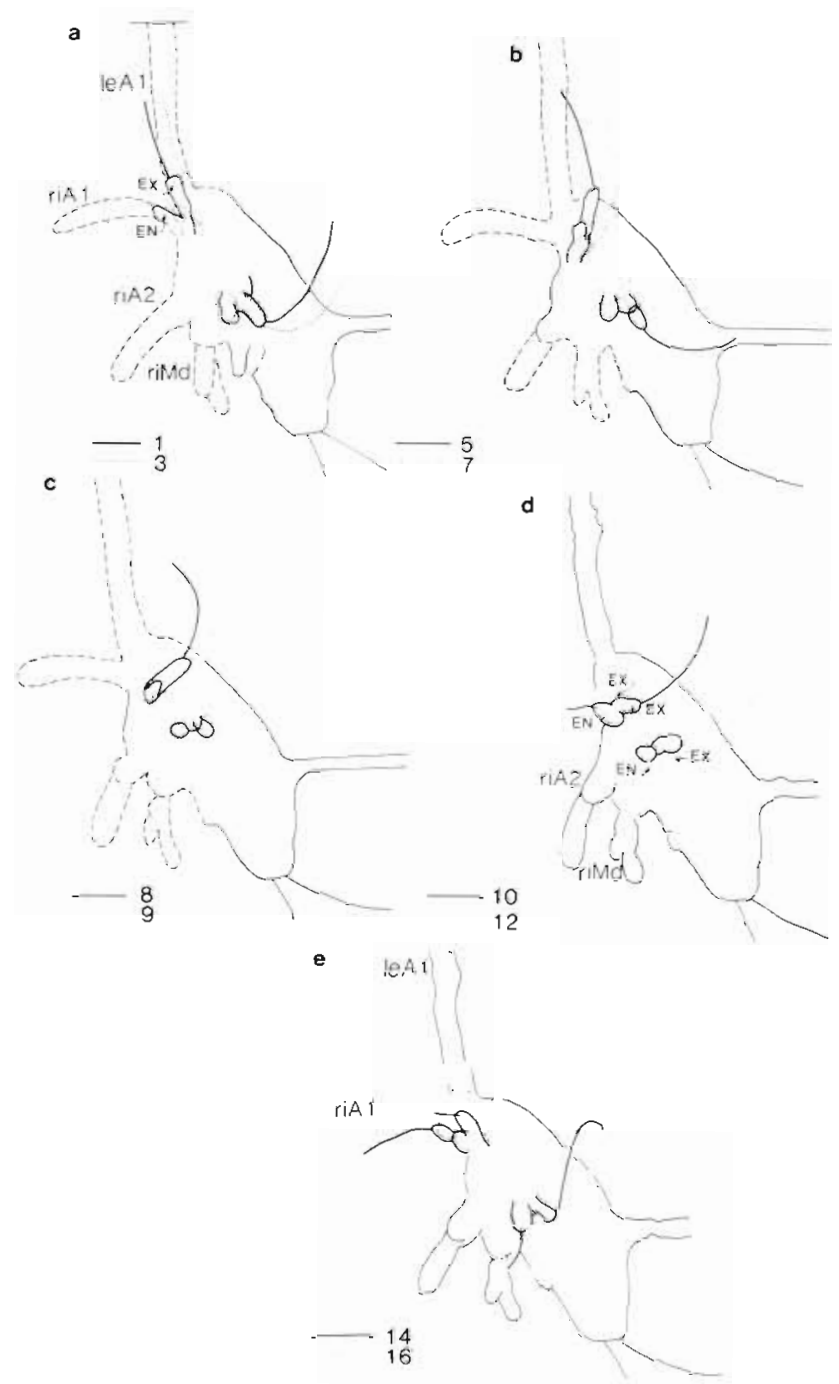

Fig. 3. Eucalanus pileatus. Same individual and position as in Fig. 2. Here we present the positions of the entire left $A 2$ and Md as we look onto them. These drawings were obtained by changing the focus continuously from the tips to the bases of these appendages over several seconds. Numbers are frame numbers; EX: exopod; EN: endopod 


\section{RESULTS}

First, we describe the motion of the appendages of tethered late nauplii of Eucalanus pileatus, and then describe the gathering of algal cells by tethered and free-swimming nauplii. Finally, we compare several variables affecting the feeding behavior of juveniles of E. pileatus and E. hyalinus.

Eucalanus pileatus nauplii have 2 pairs of appendages which enable them to swim: the second antennae (A2) and the mandibles (Md). Nauplius stages 4 to
6 (N4 to 6) of $E$. pileatus move these appendages continuously in a manner which results in very slow swimming and creation of a weak feeding current (Fig. 1): left appendages move clockwise, right appendages counter-clockwise when viewed ventrally. One pair of appendages would be insufficient to create a directed feeding current. Close observation reveals that the velocity of movement of these appendages varies during a cycle (Fig. 2). The cycle starts with frame 1, ends at 16, and lasts $64 \mathrm{~ms}$. The view is ventro-laterally, perpendicular to the nauplius' body axis. The dots

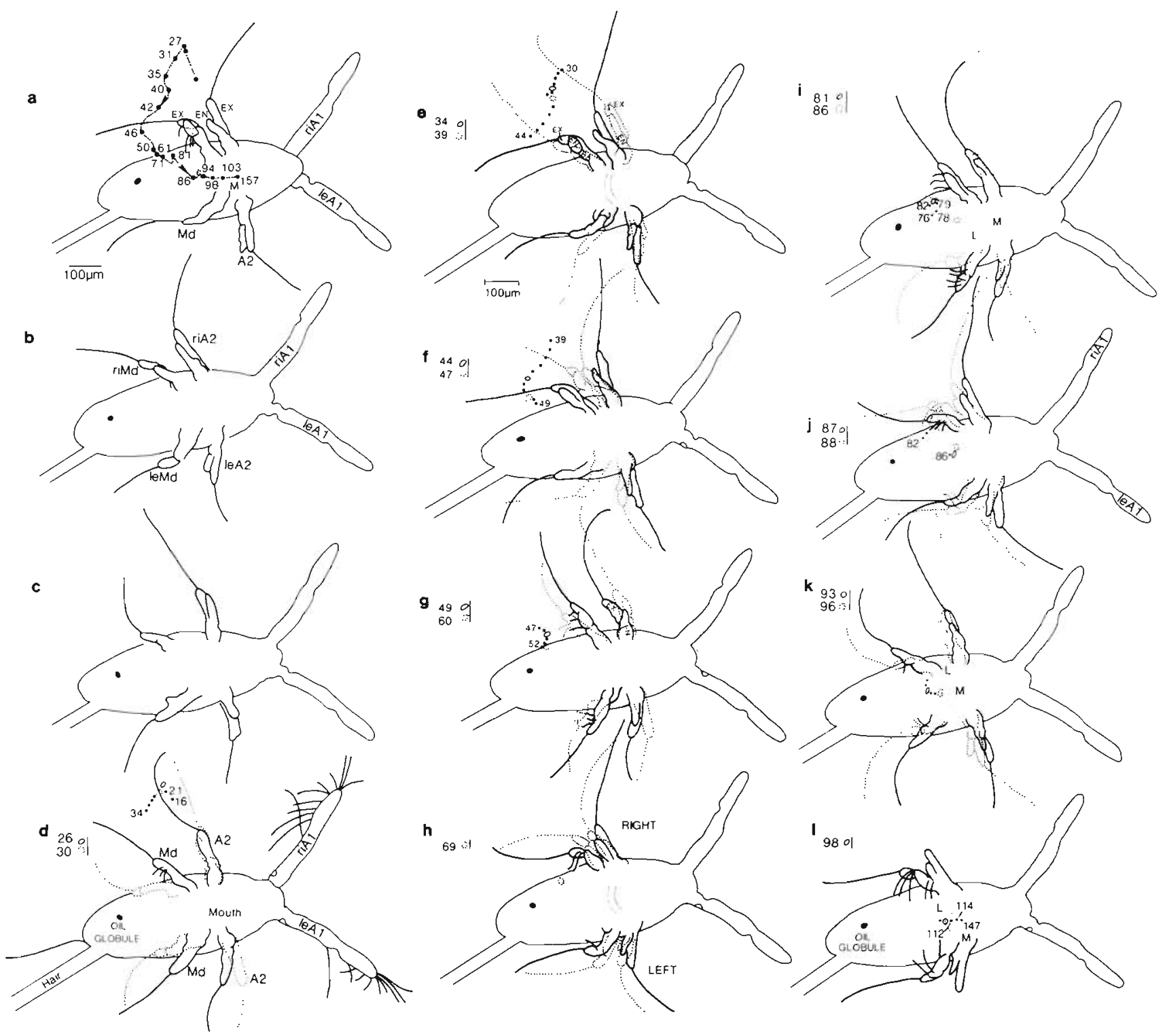

Fig. 4. Eucalanus pileatus. Ventral view of an N6. Time-series of positions of A2 and Md from prior to sensing and gathering a Thalassiosira weissflogii cell to its ingestion, and of the path which the cell takes during that period. (a) Cell positions from prior to its perception to its full ingestion. (b, c) Positions of the A2 and Md, as they are respectively, closest to and farthest, away from each other while creating a feeding current prior to the cell's perception. (d to l) The time-series. Single dots on each individual drawing prior, between and/or after the position of the cell during the 2 frames of each drawing represent all positions prior, between or after the 2 main frames. L: labrum, M: mouth 
represent the positions of the tip of the exopod of the left $\mathrm{A} 2$ and $\mathrm{Md}$. As the left $\mathrm{A} 2$ moves away from the right A2 its velocity does not change (frames 1 to 7 ); velocity increases slightly as the $\mathrm{A} 2$ and $\mathrm{Md}$ move towards each other (frames 7 to 10) and increases markedly as the A2 move away from the Md (frames 12 to 14) followed by deceleration (14 to 16 to 1). During the same time the Md travel only about one-third of the distance traveled by the A2. Circular or ellipsoidal motion of the 4 appendages at changing velocities would probably not result in the net displacement of water towards and past the nauplius. A feeding current is created mainly by 3-dimensional asymmetric motions of the A2 (Fig. 3 , right A2 and Md out of focus): as the right and left A2 move apart from each other, their endo- and exopods move in a plane perpendicular to their motion, pulling in water between them (frames 1 to 7, Fig. 3). When A2 and Md move towards each other, the A2 pass through the water in a cutting manner (exo- is following endopod) creating little resistance and drag (frames 7 to 10), and therefore displacing only small amounts of water away from the nauplius. The same occurs when the left and right A2 move towards each other (frames 10 to 12). This is followed by the A2 moving rapidly away from the $\mathrm{Md}$ (frames 12 to 14 ) pulling water in between these 2 appendages. Thus, to displace water towards itself the nauplius utilizes both $\mathrm{A} 2$ (frames 1 to 7 ), and each $\mathrm{A} 2$ with its respective $\mathrm{Md}$ (frames 12 to 14 ).

The procedure used to gather and capture an algal cell perceived by the nauplius (Fig. 4) is similar to that used by adult females (Paffenhöfer et al. 1982). As an example, we present an entire sequence from prior to the sensing of a cell of Thalassiosira weissflogii to its ingestion by a Eucalanus pileatus N6 viewed ventrally

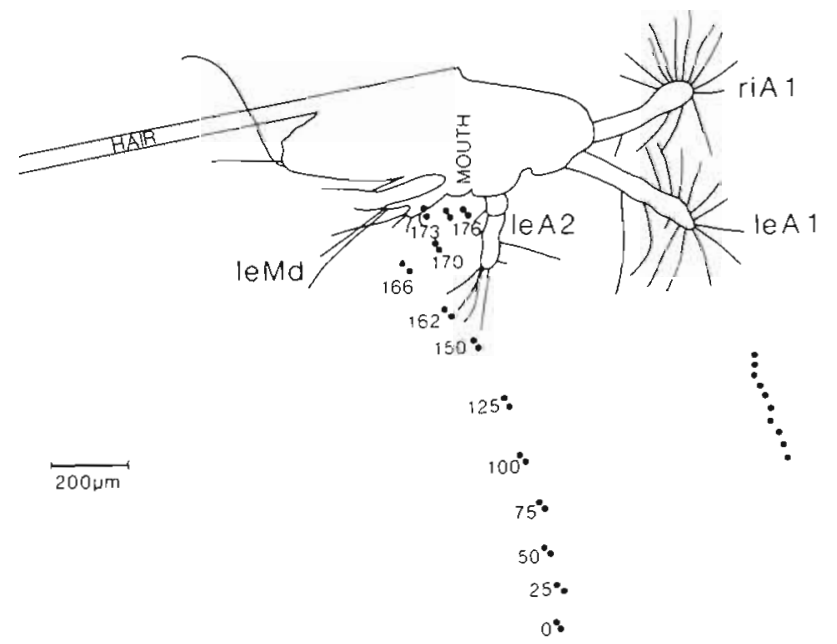

Fig. 5. Eucalanus crassus. Latero-ventral new of an N6 Gathering and capture of a chain of 2 Thalassiosira weissflogii cells
(Fig. 4). First, the entire route of that algal cell from perception to ingestion is shown (Fig, 4a). Next are the positions when the 2 pairs of appendages are closest to (Fig. 4b) and farthest apart from each other (Fig. 4c) when no algae are sensed or gathered. The position of left and right appendages are here symmetrical. The time elapsed between 2 frames is $4 \mathrm{~ms}$. We could usually recognize the endo- and exopod of the left $\mathrm{Md}$, and the right and left A2. The nauplius began its gathering efforts near frame 26 by unusual motions of its right $\mathrm{A} 2$ (Fig. 4d). The cell, being in about the same plane as the appendages, was then displaced towards the nauplius' posterior by coordinated motions of the right A2 and Md (Fig. 4e), and eventually was moved anteriorly (frames 44 to 49 ). The nauplius' behavioral response to the sensed cell is again seen by different positions of the right $\mathrm{A} 2$ and $\mathrm{Md}$ compared to their left counterparts (Fig. 4f). Further appendage motions (Fig. $4 \mathrm{~g}, h, i$, frames 49 to 82 ) moved the cell close to the nauplius' body, but not much closer to its mouth, until the combined inward motion of both $\mathrm{Md}$, in particular their endopods, displaced the cell anteriorly (Fig. 4i, frames 82 to 86 ). During the ensuing motion of the appendage the cell was displaced counter-clockwise and arrived at the labrum (L, Fig. 4j, k). Then 19 frames ( $76 \mathrm{~ms}$ ) elapsed before it was brought into the mouth (Fig. 4l, frame 114). The period from the nauplius' response to cell sensing (frame 26) to its ingestion (frame 114) was $348 \mathrm{~ms}$. The average period from response to ingestion of a $T$. weissflogii cell by $N 5 / 6$ is $183 \pm 21 \mathrm{~ms}$ (standard error, $\mathrm{n}=16$ ).

Most algal cells captured by a Eucalanus crassus nauplius are displaced towards it by a feeding current (Fig. 5, the same as observed for E. pileatus N). The velocity at which cells are transported towards the nauplius increased with increasing proximity. In this case (Fig. 5) the chain of 2 Thalassiosira weissflogii cells was transported at $0.43 \mathrm{~mm} \mathrm{~s}^{-1}$ (frames 0 to $25, \mathrm{ca}$ $1 \mathrm{~mm}$ away from nauplius' mouth) and attained 1.11 $\mathrm{mm} \mathrm{s}^{-1}$ just prior to being sensed (frames 150 to 162). After being perceived (chain is $118 \mu \mathrm{m}$ away from tip of A2) the chain was rapidly displaced posteriorly towards the $\mathrm{Md}$ (frames 162 to 166 ) at $4.7 \mathrm{~mm} \mathrm{~s}^{-1}$, then was brought forward towards the mouth mainly by motions of the Md and disappeared (was ingested) after frame 176. Cells outside of the cone of feeding current (the dots ventrally of the A1) were displaced slowly, here at $0.13 \mathrm{~mm} \mathrm{~s}^{-1}$, and were presumably not perceived by the nauplius.

Late naupliar stages of Eucalanus crassus and E. pileatus can capture and ingest phytoplankton cells almost as long as the nauplius itself. In the example given here (Fig. 6), an E. crassus N6 displaced a Rhizosolenia alata cell of $32 \mu \mathrm{m}$ width and $201 \mu \mathrm{m}$ length (without spines) towards itself with velocity 
Fig. 6. Eucalanus crassus. Same position and nauplius as in Fig. 5. Gathering, capture and ingestion of a Rhizosolenia alata cell



perception to $100 \%$ ingestion of a $R$, alata cell was $1170 \pm 189 \mathrm{~ms}$ (standard error, $\mathrm{n}=10$ ). $R$. alata cell ingestions require more time because these cells must be repeatedly repositioned to a favorable ingestionangle using 2 so-called 'masticatory' hooks on each A2's coxopod (Björnberg 1967).

Observations of free-swimming nauplii confirmed the existence of a feeding current (Fig. 7, and observations on Eucalanus pileatus nauplii). At a distance of about $0.8 \mathrm{~mm}$ from the nauplius' mouth (frames 0 to $50)$, the cell velocity ranged from 0.2 to $0.4 \mathrm{~mm} \mathrm{~s}^{-1}$, and cell was perceived and was completed in $728 \mathrm{~ms}$, thus amounting to a total of $1176 \mathrm{~ms}$. The average time from increasing from 0.66 (frame 0) to $0.93 \mathrm{~mm} \mathrm{~s}^{-1}$ (frame 30) over the distance observed. At a distance of $276 \mu \mathrm{m}$ started its flick displacing the cell posteriorly (frame 43). At the same time the Md began to respond, moving the cell towards themselves (frames 43 to 64). By motions of the Md endopods and both A2, the cell was then moved anteriorly, always at a near right angle to the nauplius' body. Ingestion started $448 \mathrm{~ms}$ after the
Fig. 7. Eucalanus crassus. Free-swimming N5. The cell's and the nauplii's positions are shown as the latter draws the former towards itself Filmed at 250 frames $\mathrm{s}^{-1}$
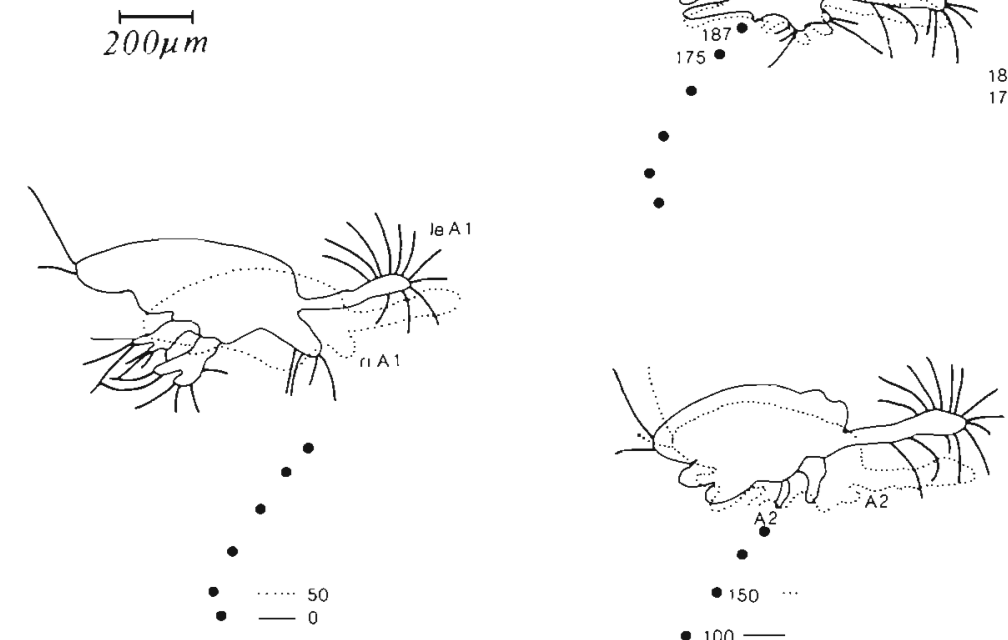

- 100 
increased to up to 1.25 to $2 \mathrm{~mm} \mathrm{~s}^{-1}$ (Fig. 7, frames 175 to 187 ). During this period the nauplius swam in various directions, attaining a maximum speed of $0.87 \mathrm{~mm} \mathrm{~s}^{-1}$. Other free-swimming nauplii of E. pileatus and E. crassus also showed multidirectional swimming behavior. Nauplii of the oceanic E. hyalinus, however, do not appear to create a feeding current. Their approach to encountered food particles seems to be limited to forward and circular swimming.

Late nauplii of Eucalanus pileatus (N5 to 6) are characterized by continuous motions of their appendages (Table 1) irrespective of whether they were tethered or free-swimming. Their appendage frequencies did not differ significantly (Mann-Whitney U-test, $p>0.20)$. Its first copepodid stage (C1), however, spent on average one-third of its time idle and moved its appendages significantly faster than the nauplii $(\mathrm{p}<$ 0.01 ). Late nauplii and early copepodids of the oceanic E. hyalinus spent on average 56 and $78 \%$, respectively, of their time idle (Table 1). Here appendage frequencies differed greatly between N5/6 and C1/2 ( $p<0.01)$. They both have in common relatively short active and passive periods. These data indicate pronounced differences in the appendage motion behavior within and between 2 closely related calanoid species.

\section{DISCUSSION}

Morphology, anatomy, function of appendages and behavior of nauplii of various crustacean species have been recently compared and discussed (Fryer 1986). It became obvious that our knowledge on the behavior of the most abundant metazoan, the nauplius (Fryer 1986), is restricted to a few observations on living specimens (e.g. Gauld 1958, Fryer 1983, Björnberg 1986); the scarcity of information includes nauplii of calanoid copepods. Previous evidence on food gathering of calanoid nauplii is controversial: nauplii of Diaptomus gracilis use their A2 and Md to create, through rhythmic vibration, continuous currents which direct particles towards the mouth nearby which these particles would be retained by filtration (Storch 1928). Gauld (1958) found no evidence of particle transportation to the mouth by water currents by calanoid nauplii. The naupliar A2 would serve mainly as locomotory organs, and the Md for food collection but also participate in locomotion.

Most of our evidence on nauplii of Eucalanus pileatus, E. crassus and E. hyalinus comes from numerous cinematographic observations of tethered and freeswimming specimens. The first 2 species create a current using coordinated motions of the A2 and $\mathrm{Md}$ (Figs. 1 and 2). This current is largely due to the asymmetrical, 3-dimensional and continuous motions of the A2 (Figs. 2 and 3). In this current particles are transported towards the nauplius, and are actively gathered by oriented responses of the A2 and the Md (Fig. 3). This active gathering behavior resembles that of adult females of $E$. pileatus and $E$. crassus (Paffenhöfer et al. 1982). It appears that phytoplankton cells are perceived at a certain distance from the nauplius' body. Nauplii of E. crassus and E. pileatus respond to Thalassiosira weissflogii and Rhizosolenia alata when they are on average 92 and $276 \mu \mathrm{m}$, respectively, away from the tips of their A2 and $\mathrm{Md}$. For comparison, adult females of $E$. pileatus react to incoming phytoplankton cells when they are as far away as $1250 \mu \mathrm{m}$ (Strickler 1982). We assume the following scenario for cell perception by E. pileatus/crassus nauplii: since chemoreceptors have been found on distal parts of setae of calanoid mouthparts (Friedman \& Strickler 1975), and the length of setae of the A2 and $\mathrm{Md}$ of our nauplii ranged from about 90 to $310 \mu \mathrm{m}$,

Table 1. Eucalanus spp. Appendage frequencies and active/passive periods of late nauplii and early copepodid stages feeding on the diatom Thalassiosira weissflogil

\begin{tabular}{|c|c|c|c|c|c|}
\hline \multirow[b]{3}{*}{ Stage } & \multicolumn{3}{|c|}{ Eucalanus pileatus } & \multirow{2}{*}{\multicolumn{2}{|c|}{$\begin{array}{c}\text { Eucalanus hyalinus } \\
\text { Free-swimming }\end{array}$}} \\
\hline & \multicolumn{2}{|c|}{ Tethered } & \multirow{2}{*}{$\begin{array}{l}\text { Free-swimming } \\
\text { N5 to } 6\end{array}$} & & \\
\hline & N5 to 6 & $\mathrm{C} 1$ & & N4 to 6 & $\mathrm{C} 1$ to $\mathrm{C} 2$ \\
\hline $\mathrm{n}$ & 5 & 6 & 6 & 8 & 4 \\
\hline Appendage frequency $(\mathrm{Hz})$ & $16.3 \pm 0.9$ & $26.2 \pm 1.5$ & $15.8 \pm 0.8$ & $4.8 \pm 0.6$ & $17.4 \pm 3.3$ \\
\hline Average active period (ms) & Continuous & $1186 \pm 697$ & Continuous & $256 \pm 92$ & $121 \pm 28$ \\
\hline Average passive period (ms) & None & $573 \pm 191$ & None & $318 \pm 97$ & $422 \pm 132$ \\
\hline Passive period as $\%$ of total time & 0 & $33.2 \pm 11.7$ & 0 & $56.1 \pm 3.8$ & $77.6 \pm 6.4$ \\
\hline Food concentration $\left(\mathrm{mm}^{3} \mathrm{l}^{-1}\right)$ & 0.98 to 1.1 & 1.0 & 1.0 to 3.0 & 1.0 to 30 & 1.0 to 3.0 \\
\hline $\begin{array}{l}\text { n: number of individuals studied } \\
\pm: 95 \% \text { confidence limits }\end{array}$ & & & & & \\
\hline
\end{tabular}


these nauplii sensed phytoplankton cells ( $T$. weissflogii and $R$. alatal in the immediate proximity of these setae, i.e. only a few um away. In theory, the distance at which calanoids perceive phytoplankton cells should decrease with decreasing velocity of the feeding current because of a reduction of the deformed space around the cell (Andrews 1983). The feeding currents of our nauplii were weak in comparison to those of their adult females. Since the feeding currents of nauplii of E. crassus/pileatus approach ventrally, they cannot use their first antennae (A1) to perceive approaching particles as copepodids and females seem to be able to do (Strickler 1982). Thus, long-distance perception of phytoplankton cells, as observed for adult females, does not appear to be in the repertoire of these nauplii. Although nauplii, copepodids and adult females can gather and ingest elongated particles, such as diatoms of the genus Rhizosolenia, we observed some distinct differences: while adult females of $E$. crassus use the endites of their first maxillae to position a $R$. alata cell at their mouth (Paffenhöfer et al. 1982), nauplii of this species use so-called 'masticating hooks' of the A2 to position $R$. alata prior to ingestion, and re-position them during this process. These hooks disappear when the nauplius molts to $C 1$. While all feeding stages of $E$. pileatus have the active feeding mode in common, nauplii do not feed passively like copepodids and adult females (Price et al. 1983). They lack the second maxillae (M2), or a similar structure, to passively collect small particles (Price \& Paffenhöfer 1986a). Therefore, their spectrum of utilizable food sizes should be narrower than that of a copepodid stage 1 which is similar in size (Fernandez 1979, p. 140, Calanus pacificus).

The food-gathering behavior described for nauplii of Eucalanus pileatus and E. crassus, however, does not necessarily apply to nauplii of all other species of planktonic copepods. Observations by Uchima \& Hirano (1986) on the food of nauplii of the cyclopoid Oithona davisae lead us to hypothesize that they almost exclusively perceive and gather motile particles. Nauplii of the cyclopoid Oncaea sp. are motionless most of the time and do not create feeding currents; similar to nauplii of $O$. davisae, they ingest few diatoms but many flagellates of a similar volume (pers. obs.). We assume that these cyclopoid nauplii perceive their food mainly with mechanosensors, while Eucalanus nauplii use mostly chemosensors. So far there appear to be 3 types of behavior of free-swimming copepod nauplii for encountering food particles: (1) by swimming (e.g. E. hyalinus), (2) by letting the food come towards themselves (e.g. Oncaea sp.), and (3) by swimming, and displacing food towards themselves with a feeding current (e.g. E. pileatus and E. crassus).

While morphological differences of appendages between late copepodids/adult females of different calanoid species can be pronounced, e.g. comparing the maxillipeds of Acartia tonsa with those of Paracalanus parvus and Eucalanus pileatus, few differences are found in the appendages of their nauplii (A2 and Md). Small morphological differences, however, do not preclude behavioral differences. Nauplii may be similar in size, or closely related like those of E. pileatus and $E$. hyalinus, but differ in species-specific behavior (Table 1): whereas N5 and N6 of E. pileatus move their mouthparts continuously at about $16 \mathrm{~Hz}$, E. hyalinus N4 to 6 move them only $56 \%$ of the time and at $4.8 \mathrm{~Hz}$.

By comparison, adult females of Eucalanus pileatus take infrequent breaks (move appendages almost continuously), whereas those of E. hyalinus spend as much as $70 \%$ of their time without appendage movement (Price \& Paffenhöfer 1986b). This similarity in behavior between nauplius and adult female indicates that certain behaviors are indeed species-specific, while others, such as capture of large phytoplankton cells with oriented appendage motions, are not. Swimming, at least in quite a number of calanoids, contributes to finding food particles, but has received little attention in this article. To include this variable, our future studies on intra- and interspecific comparisons of copepod feeding behavior will focus on free-swimming organisms.

To understand the significance of calanoid copepods in aquatic ecosystems, a thorough knowledge, not only of the behavior of adult stages, but also that of juveniles is required. The percentage of nauplii which reach older stages and adulthood determines that species' contribution to, impact on, and survival of the species within its respective ecosystem.

Acknowledgements. This research was supported by Grants OCE85-00917 and OCE87-23174 from the National Science Foundation. We thank Drs G. Fryer, T. Kiørboe, D. W. Menzel and H. A. Vanderploeg for their thorough review of an earlier version of this paper, Suzanne Mcintosh and Anna Boyette for preparing the figures, and Dannah McCauley for typing the manuscript.

\section{LITERATURE CITED}

Alcaraz, M., Paffenhöfer, G.-A., Strickler, J. R. (1980). Catching the algae: a first account of visual observations on filter feeding calanoids. In: Kerfoot, W. C. (ed.) The evolution and ecology of zooplankton communities. Univ. Press of New England, p. 241-248

Andrews, J. C. (1983). Deformation of the active space in the low Reynolds number feeding current of calanoid copepods. Can. J. Fish. Aquat. Sci. 40: 1293-1302

Björnberg, T. K. S. (1967). The larvae and young forms of Eucalanus dana (Copepoda) from tropical Atlantic waters. Crustaceana 12: 59-73

Björnberg, T K. S. (1986). Aspects of the appendages in development. Syllogeus 58: 51-66

Bowman, T. E. (1971). The distribution of calanoid copepods 
off the southeastern United States between Cape Hatteras and Southern Florida. Smithson. Contrib. Zool. 96: 1-58

Cowles, T J., Roman, M. R., Gauzens, A. L., Copley, N. J (1987). Short-term changes in the biology of a warm-core ring: zooplankton biomass and grazing. Limnol. Oceanogr 32: 653-664

Fernandez, F. (1979). Nutrition studies on the nauplius larva of Calanus pacificus (Copepoda: Calanoida). Mar. Biol. 53: 131-147

Fleminger, A. (1973). Pattern, number, variability, and taxonomic significance of integumental organs (sensilla and glandular pores) in the genus Eucalanus (Copepoda, Calanoida). Fish. Bull. U.S. 71: 965-1010

Friedman, M. M., Strickler, J. R. (1975). Chemoreceptors and feeding in calanoid copepods (Arthropoda: Crustacea) Proc. natn. Acad. Sci. USA 72: 4185-4188

Frost, B. W (1987). Grazing control of phytoplankton stock in the open subarctic Pacific Ocean: a model assessing the role of mesozooplankton, particularly the large calanoid copepods Neocalanus spp. Mar. Ecol. Prog. Ser. 39: 49-68

Fryer, G. (1983). Functional ontogenetic changes in Branchinecta ferox (Milne-Edwards) (Crustacea: Anostraca). Phil. Trans. R. Soc. Lond. B. 303: 229-343

Fryer, G. (1986). Structure, function and behavior and the elucidation of evolution in copepods and other crustaceans. Syllogeus 58: 150-157

Gauld, D. T (1958). Swimming and feeding in crustacean larvae: the nauplius larva. Proc. Zool. Soc. Lond. 132: 31-50

Gauld, D. T. (1966). The swimming and feeding of planktonic copepods. In: Barnes, H. (ed.) Some contemporary studies in marine science. Allen and Unwin, London, p. 313-334

Koehl, M. A. R., Strickler, J. R. (1981). Copepod feeding currents: food capture at low Reynolds number. Limnol. Oceanogr. 26: 1062-1073

Marshall, S. M., Orr, A. P. (1956). On the biology of Calanus finmarchicus. IX. Feeding and digestion in the young stages. J. mar. biol. Ass. U.K. 35: 587-603

This article was submitted to the editor
Paffenhöfer, G.-A. (1970). Cultivation of Calanus helgolandicus under controlled conditions. Helgoländer wiss Meeresunters 20: 346-359

Paffenhöfer, G.-A. (1984). Food ingestion by the marine planktonic copepod Paracalanus in relation to abundance and size distribution of food. Mar Biol. 80: 323-333

Paffenhöfer, G.-A., Deibel, D., Atkinson, L. P., Dunstan, W. M. (1980). The relation of concentration and size distribution of suspended particulate matter to hydrography in Onslow Bay, North Carolina. Deep Sea Res. 27A: 435-447

Paffenhofer, G.-A., Strickler, J. R., Alcaraz, M. (1982). Suspension-feeding by herbivorous calanoid copepods: a cinematographic study. Mar. Biol. 67: 193-199

Price, H. J., Paffenhöfer, G.-A. (1986a). Capture of small cells by the copepod Eucalanus elongatus. Limnol. Oceanogr. 31: 189-194

Price, H. J., Paffenhöfer, G.-A. (1986b). Effects of concentration on the feeding of a marine copepod in algal monocultures and mixtures. J. Plankton Res. 8: 119-128

Price, H. J., Paffenhöfer, G.-A., Strickler, J. R. (1983). Modes of cell capture in calanoid copepods. Limnol. Oceanogr 28: $116-123$

Steele, J. H. (1974). The structure of marine ecosystems. Harvard University Press, Cambridge

Storch, O. (1928). Der Nahrungserwerb zweier Copepodennauplien (Diaptomus gracilis und Cyclops strenuus). Zool. Jb. allgm. Zool. Physiol. 45: 385-436

Strickler, J. R. (1982). Calanoid copepods, feeding currents, and the role of gravity. Science 218: $158-160$

Strickler, J. R. (1984). Sticky water a selective force in copepod evolution. In: Meyer, D. G., Strickler, J. R. (eds.) Trophic interactions within aquatic ecosystems. AAAS Symposium 85, Westview Press, Boulder, p. 187-239

Uchima, M., Hirano, R. (1986). Food of Oithona davisae (Copepoda: Cyclopoida) and the effect of food concentration at first feeding on the larval growth. Bull. Plankton Soc. Japan 33: 21-28

Manuscript first received: March 23, 1989

Revised version accepted: July 3, 1989 